\section{IMPORTANCE OF SIGMOIDOSCOPE IN DIAGNOSIS OF DISEASE IN TER- MINAL COLON AND RECTUM}

\author{
WITH A DISCUSSION OF TWO HUNDRED AND \\ FIFTY-ONE CASES
}

GOLDER LEWIS McWHORTER, M.D., Ph.D. In Surgery Instructor in Surgery, Rush Medical College

CFICAGO

This study is based on a series of patients whom I examined with the protoscope or sigmoidoscope while at the Mayo Clinic, 1917. The patients, with few exceptions, had not been examined with special instruments, though nearly all of them complained of some symptoms referable to the terminal bowel or to some disease in this region. The failure to detect early the large number of diseased conditions in the terminal colon results from a neglect to examine all patients with the sigmoidoscope, however slight the symptoms. At the time of examination, I noted the chief complaints and findings, and, after the discharge of the various patients from the clinic, I reviewed carefully the histories, noting the findings, diagnoses and results of treatment. In Table 1 , I have classified all cases examined, as shown by the final diagnosis, but in this paper, shall take up only those grouped under A, $B, C$ and $D$, because of a lack of space for lengthy consideration of all cases, and because of the greater importance and gravity of the diseases in these groupings.

Disease of the large bowel is most commonly located (exclusive of the appendix) in the rectum and sigmoid ; consequently, its presence may usually be determined by inspection of this region. Leichtenstern ${ }^{1}$ states that in 770 cases of intestinal carcinoma, 616 were in the rectum, 89 in the colon, 32 in the cecum and appendix, and 33 in the small intestine. Out of 89 cases of colon carcinoma, 42 were in the flexura sigmoidea, and 30 in the transverse, 11 in the descending, and 6 in the ascending colon.

While a number of disease conditions may be discovered by the examining finger, yet inspection by means of a protoscope is necessary in the majority of cases before a definite diagnosis may be made. The majority of carcinomas are beyond reach of the finger, yet well within observation by the protoscope or sigmoidoscope. In a series of 100 consecutive cases of carcinoma of the rectum and rectosigmoid removed at St. Mary's Hospital, 63 per cent. involved the rectosigmoid region. ${ }^{2}$

Twenty-two cases of my series (Table $1 \mathrm{~A}$ ) were diagnosed carcinoma, and in only one was the carcinoma located beyond reach of the sigmoidoscope. This was removed after a roentgen diagnosis of prols. able carcinoma or diverticulitis, the carcinoma being located in the upper part of a long sigmoid. The appearance of carcinoma is usually quite characteristic, with an annular or oval ulcerated growth elevated at the edges, and a cauliflower-like appearance of the granulation tissue. In later stages, the growth may produce an almost complete stenosis of the bowel; but careful inspection of the everted edge and irregular surface of the ulcerated growth, which is hard, friable, and either circumscribed or diffuse, establishes the diag-

1. Leichtenstern, in von Ziemssen's Handbuch, Ed. 1, $\boldsymbol{\gamma}$, quoted by Strauss: Procto-Signoscopie, Leipzig, 1910. Obst., 1917, 25, 61c. nosis. The appearance of carcinoma after radium exposure is somewhat different. The surrounding tissues are edematous, somewhat indurated, and instead of the ulcerated surface having a cauliflower-lite appearance, it is quite smooth and glistening, while the new growth is less resistant, edematous and not so sharply circumscribed. The history of the disease and the application of radium, in connection with the proctoscopic examination, will enable the making of a definite diagnosis, and only in exceptional cases is it permissible to remove tissues for microscopic exam. inations.

The chief complaints in these cases (Table $1 \mathrm{~A}$ ) were blood in 21 , constipation in 15 , pain in 10 , usually in the rectum but in 1 , in the lower abdomen, pencil stools in 9 , hemorrhoids in 5 , and, in 2 cases, a long existing diarrhea. The duration of symptoms was about eight months, though in four cases, the average was only three months. In a review of 491 cases of carcinoma of the rectum and pelvic colon, Lynch $^{3}$ found the average duration to be more than eight months.

In twenty cases of chronic colitis (Table $1 \mathrm{C}$ ) the Endameba hystolytica was found. The appearance of the bowel in colitis due to the ameba is not characteristic, but in some cases in which there are multiple small oval or round ulcers, some mucus, a hyperemic, easily bleeding surface, and some edema of the wall, the ameba may be correctly diagnosed as the cause. Many cases proved amebic are of slight severity or are limited to a slight proctitis, the sigmoid appearing normal. In two of these twenty amebic cases, the moderate inflammation was limited to the rectum, and roentgenoscopy revealed no changes in the colon. From the experimental production of amebic colitis in kittens, Dale and Dobell ${ }^{4}$ found the upper and lower third of the colon most involved, especially the latter. Lynch and $\mathrm{McF}$ arland, ${ }^{5}$ in reporting chronic colitis with negative stool examination, state that in the unclassified nonamebic colitis, the sigmoid is most involved. Some of the amebic patients examined had evidences of previous severe inflammation in folds of hypertrophied or atrophic and scarred mucosa, two patients having generally contracted and rigid colons. Considerable care was used, especially in the latter cases, in passing the sigmoidoscope, to prevent tearing the mesentery or wall.

The chief complaints in the twenty amebic colitis cases were diarrhea in 14, epigastric or diffuse abdominal pain in 11 , rectal pain in 1 , blood in 6 , mucus in 4 , alternate constipation and diarrhea in 2 , constipation in 1, pus in 1, gas in 1, and frequent urination in 1 . Sanford ${ }^{6}$ found in 41 per cent. of persons affected with ameba in the temperate climate a history of constant diarrhea, in 33 per cent., intermittent diarrhea, and in 26 per cent., no bowel trouble at all except constipation, the whole syndrome being less severe than in the South or the tropics. Whitmore ${ }^{7}$ emphasizes the grave danger of the rapidly increasing number of carriers of Endameba histolytica in camp life, including many who have no intestinal symptoms. $\mathrm{He}$ states that from 20 to 25 per cent. of dysentery on the East-

3. Lynch, J. M.: Cancer of the Rectum and the Pelvic Colon, THE Journal A. M. A., Nov. 24, 1917, p. 1775 .

4. Dale and Dobell: Experiments on the Therapeutics of Amoebic Dysentery, Jour. Pharmacol. and Exper. Therap., 1917, 10, 397.

5. Lynch, J. M., and McFarland, W. L.: Colonic Infections, THE Journal A. M. A., Sept. 23, 1916, p. 943.

6. Sanford, A. H.: The Geographic Distribution of Amebiasis, TH OURNAL A. M. A. Dec. 23, 1916, p. 1923.

JoURA W A. M. A., Dec. 23, 1916, p. 1923, Its Relation to Camp Life, 7. Whitmore. E. R.: Dysentery and
Pennsylvania Med. Jour., 1918, 21, 273. 
ern front is due to the endameba, and that carriers are very resistant to treatment.

Thirteen patients with chronic colitis (Table $1 \mathrm{D}$ ) showed no specific organism on repeated stool exam. inations; consequently, they are grouped separately. Four of this group were clinically diagnosed as having amebic colitis, the remainder being classed under unknown etiology. In comparing the unclassified with the amebic group, I found the severity of the colitis much less in the latter. Only one amebic case was severe enough to require ileostomy, while in the much smaller number of unclassified chronic cases, two patients were operated on in this manner. This severe chronic colitis must not be confused with the mucous type, in which no actual inflammatory changes are seen, and for which Simon ${ }^{8}$ has suggested the name myxoneurosis. There is a true inflammation of the mucous membrane in these chronic cases of colitis, complicated by infiltration of the wall, and perhaps by peritonitis, with oftentimes erosions and ulcers as secondary changes. The stage between a simple and a severe colitis is a very gradual one. in the ileum after a meal, and accelerated in the colon, others having found the same to be true.

The chief complaints found (Table 1 D) were diarrhea in 12 , blood in 7 , abdominal pain in 3 , mucus in 4, some incontinence in 2 , and alternate constipation and diarrhea in 1 . Concerning the etiology of severe colitis with negative stool examinations, it is significant that Strauss ${ }^{10}$ in working on the serologic reaction, found a positive agglutination test consistently against the various types of dysentery, paratyphoid and typhoid bacilli in both acute and chronic cases. In only one case, that of an acute type, did he find the corresponding organism in the stool.

\section{POLYPI AND CARCINOMA}

An interesting group is seen in Table $1 \mathrm{~B}$, and is elaborated on in Table 2 . In this series are thirteen cases, in twelve of which polypi were present and in one of which there was no recurrence observable from the base of a polypus removed several months before. In one (Case 9) there was a recurrence of a polyp fulgurated ten months previously. Severe multiple

TABLE 1.-CONDITIONS FINALLY DIAgNOSED, AND MOST $F$ REQUENT COMPLAINTS IN TWO HUNDRED AND FIFTY-ONE CONSECUTIVE CASES

\begin{tabular}{|c|c|c|c|c|c|c|c|}
\hline Conditions Present & $\begin{array}{c}\text { Number } \\
\text { of } \\
\text { Cases }\end{array}$ & Blood & $\begin{array}{l}\text { Diar- } \\
\text { rhea }\end{array}$ & $\begin{array}{l}\text { Constí- } \\
\text { pation }\end{array}$ & $\begin{array}{c}\text { Consti- } \\
\text { pation } \\
\text { and } \\
\text { Diar. } \\
\text { rhea }\end{array}$ & $\begin{array}{l}\text { Average } \\
\text { Duration } \\
\text { of Symp- } \\
\text { tomis, } \\
\text { Months }\end{array}$ & Remarks \\
\hline  & $\begin{array}{r}22 \\
12 \\
20 \\
13 \\
7 \\
4 \\
2 \\
14 \\
6 \\
13 \\
3 \\
10 \\
50 \\
2 \\
7 \\
1 \\
1 \\
6 \\
58\end{array}$ & $\begin{array}{r}21 \\
7 \\
6 \\
7 \\
\ddot{1} \\
\because . \\
\because \\
\ddot{3} \\
2 \\
5 \\
30 \\
\ddot{2} \\
\because . \\
\because . \\
\because .\end{array}$ & $\begin{array}{r}2 \\
4 \\
14 \\
12 \\
\because . \\
\ddot{.} \\
\ddot{2} \\
\ddot{2} \\
\ddot{2} \\
\ddot{4} \\
\because \\
\because \\
\because \\
\because . \\
\because \\
\cdots\end{array}$ & 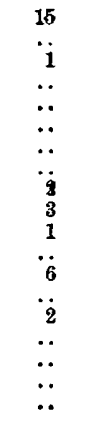 & 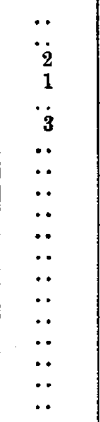 & $\begin{array}{r}8 \\
16 \\
56 \\
14 \\
\ldots \\
\ldots \\
\ldots \\
12 \\
\ldots \\
\ldots \\
\ldots \\
108 \\
96 \\
\ldots \\
4 \\
\ldots \\
\ldots \\
\ldots \\
\ldots .\end{array}$ & $\begin{array}{l}\text { Three had slight proctitis, one of them a polyr } \\
\text { Several had advanced hemorrhoids } \\
\text { One case was prolapse of sigmoid } \\
\text { These were all the result of some operation } \\
\text { The most frequent complaint was of hemorrhoids } \\
\text { Prolapse of rectum and hemorrhoids, } 20 \text { years }\end{array}$ \\
\hline
\end{tabular}

Roentgenoscopy is of value in chronic colitis because of its aid in determining predisposing causes, as stasis, chronic obstruction, and diverticula, or in estimating the extent and amount of involvement due to secondary changes. Kienböck ${ }^{9}$ describes two types of colitis ulcerosa as determined by the roentgen ray from five to twelve hours after the meal, immediately after, and one hour after, an opaque enema. (The use of the enema for roentgenoscopy should be avoided in very acute or severe chronic cases, as it may lead to perforation.) The colon, in the first type described by Kienböck, is narrow, may be spastically contracted, and is nearly or entirely haustraless with uneven flecking of the edges; in the second type, it is relatively broad, and almost invisible, owing probably to its being filled with slimy mucus and nearly bismuth-free contents; or, if visible, it presents the appearance of a very light, haustraless cylinder, owing to its being filled with air, and has a characteristic uneven bismuth flecking throughout. In chronic ulcerative colitis, Kienbock found the progress of the bismuth retarded

8. Simon, S. K.: Mucous Colitis and Its Treatment, New Orleans Med. and Surg. Jour., 1916, 69, 25.

9. Kienböck, R.: Zur Röntgendiagnose der Colitis, ulcerosa, Fortschr. a. d. Geb. d. Röntgenstrahlen, 1913, 20, 230. polyposis was found in one (Case 11) in which deep ulcerations and a severe inflammation of the colon later became complicated by multiple perforations and ended in death. In the remaining cases there were only solitary or a few scattered polypi; however, there is significance in the fact that in three of these (Cases 2,3 and 7) a carcinoma was also present. While multiple polyposis of the colon has been recognized for many years as a serious disease because of the frequent consequent development of carcinoma, the importance of the association of isolated or of a few scattered polypi with carcinoma has not been emphasized; consequently, the treatment of these polypi, and of local inflammation, has been neglected.

Whether the same conditions call forth both carcinoma and polypi, whether the carcinoma is secondary to the polypi, or vice versa, has not been established. Recently, Soper, ${ }^{11}$ in reporting a case of his own, reviewed the literature of multiple polyposis, and found sixty cases. Carcinoma was present in 43 per cent. of these, appearing much more frequently in the rectum. The etiology of multiple polyposis is not

10. Strauss, H: Zur Aetiologie der Dysenterie und dysenterieähnlicher Erkrankungen, Arch. f. Verdauungskr., 1915, 21, 16. 151. 405 . 
clear. Although most frequent in young persons, yet even here there is early carcinoma involvement. That there may be some familial relationship between carcinoma and multiple polyposis is shown by Doering, ${ }^{12}$ who reports that out of fifty patients, eight were members of families in which other members had died from carcinoma of the rectum. The polypi vary from the size of a pigeon's egg to very minute dimensions.

Most authors classify two chief types of polypi and believe that either type may occasionally be multiple, producing the disease multiple polyposis. In the first type, the adenoma or increased gland formation may form a superficial infiltration into the wall, or else project as a polypus. In the second type, the polypoid tumor is composed of solid connective tissue from the submucosa, or of branching tufts covered with more that there is no sharp line between these tumors and carcinomas.

It is the belief of many that these polypi originate from congenital rests, and are absolute new growths. ${ }^{16}$

Versé $^{17}$ assumes a congenital predisposition of the epithelial cells to increased proliferation, which through stimulation by chronic inflammation leads to polyp formation. Borelius and Sjovall ${ }^{18}$ conclude that all supposed characteristic differences between polypi of primary new growth and those secondary to inflammatory origin are shown untenable, and that there is no hindrance to the belief that all intestinal polypi can start on an inflammatory basis. Wechselmann ${ }^{19}$ thought that the inflammatory hyperplastic polyposis, as contrasted with new growths, was limited to the mucosa possessing no pedicle from the submucosa.

TABLE 2.-THIRTEEN CASES, IN TWELVE OF WHICH ISOLATED OR MULTIPLE POLYPI WERE PRESENT

\begin{tabular}{|c|c|c|c|c|c|c|c|}
\hline No. & Chief Complaints & Polypi & $\begin{array}{l}\text { Number } \\
\text { of Polypi }\end{array}$ & Age & $\operatorname{Sex}^{*}$ & Complieations & Remarks \\
\hline 1 & $\begin{array}{l}\text { Blood in stools, diarrhea and } \\
\text { bowel distress, } 1 \text { year }\end{array}$ & $\begin{array}{l}1 \text { in rectum; } 4 \text { or } 5 \text { in lower } \\
\text { sigmoid }\end{array}$ & $5-6$ & 26 & 8 & Severe colitis & $\begin{array}{l}\text { On examination, one polyp fouml } \\
\text { to be an adenoma }\end{array}$ \\
\hline 2 & $\begin{array}{l}\text { Blood and hemorrhoids, } 10 \\
\text { years; pain in rectum, } 1 \\
\text { year }\end{array}$ & $\begin{array}{l}5 \text { or } 6 \text { in rectum and lower sig- } \\
\text { moid; bean sized to hazelnut }\end{array}$ & $5 \cdot 6$ & 43 &  & $\begin{array}{l}\text { Careinoma, } \\
5 \mathrm{~cm} \text {. up rectum }\end{array}$ & Kraske operation done \\
\hline 3 & $\begin{array}{l}\text { Hemorrhoids, } 10 \text { years, con- } \\
\text { stipation and blood, } 9 \\
\text { months }\end{array}$ & 1 sessile pea sized rectal polyp & 1 & 47 & 0 & $\begin{array}{c}\text { Carcinoma, } \\
3 \mathrm{~cm} \text {. up rectum }\end{array}$ & $\begin{array}{l}\text { Metastases found in liver; chronic } \\
\text { infammation in polyp }\end{array}$ \\
\hline 4 & $\begin{array}{l}\text { Abdominal pain, diarrhea and } \\
\text { mucus }\end{array}$ & 1 in lower sigmoid & 1 & 39 & 8 & $\begin{array}{l}\text { Spastic } \\
\text { sphineter }\end{array}$ & \\
\hline 5 & Diarrhea, 3 years & 1 small polyp in lower rectum & 1 & 35 & 0 & $\begin{array}{l}\text { Ameba histo- } \\
\text { lytica present }\end{array}$ & $\begin{array}{l}\text { On examination, polyp shows } \\
\text { chronic inflammation }\end{array}$ \\
\hline 6 & $\begin{array}{l}\text { Constipation and hemor- } \\
\text { rhoids } 20 \text { years; blood, } 1 \\
\text { year }\end{array}$ & $\begin{array}{l}1 \text { lower sigmoid, bean size; } 2 \\
\text { small ones, lower rectum }\end{array}$ & 3 & 59 & 8 & & 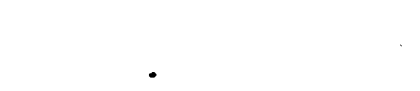 \\
\hline 7 & $\begin{array}{l}\text { Hemorrhojds, pain, blood and } \\
\text { ribbon stools, } 1 \text { year }\end{array}$ & 1 bean sized in lower rectum & 1 & 67 & $\delta$ & $\begin{array}{l}\text { Careinoma, } \\
8 \mathrm{em} \text {. up rectum }\end{array}$ & $\begin{array}{l}\text { Tube resection of bowel done (peri- } \\
\text { tonitis) }\end{array}$ \\
\hline 8 & Piles and spasm of sphincter & 1 bean sized in lower rectum & 1 & 30 & $\sigma^{\prime}$ & Hemorrhoids & \\
\hline 8 & Slight incontinence of feces & $\begin{array}{l}1 \text { pea sized, upper rectum, re- } \\
\text { current; 2-3 small ones, lower } \\
\text { sigmoid }\end{array}$ & 3 & 38 & $0^{*}$ & & $\begin{array}{l}\text { Recurrence of one polyp fulgurated } \\
10 \text { months before }\end{array}$ \\
\hline 10 & $\begin{array}{l}\text { Diarrhea, constipation, mu- } \\
\text { cus and blood, } 2 \text { years }\end{array}$ & 1 bean sized in lower rectum & 1 & so & q & $\begin{array}{l}\text { Severe uicera- } \\
\text { tive colitis }\end{array}$ & No amebas found \\
\hline 11 & $\begin{array}{l}\text { Severe pain, diarrhea, blood } \\
\text { and mucus, } 8 \text { months }\end{array}$ & $\begin{array}{l}\text { Extensive, ulcerative, polyposis } \\
\text { colon }\end{array}$ & $\begin{array}{l}\text { Multiple } \\
\text { through- } \\
\text { out colon }\end{array}$ & 35 & q & $\begin{array}{l}\text { Multiple per- } \\
\text { forations one } \\
\text { month later }\end{array}$ & $\begin{array}{l}\text { Pathologically, extensive diffuse } \\
\text { papillomatous colitis with mul- } \\
\text { tiple ulcers and perforations }\end{array}$ \\
\hline 12 & $\begin{array}{l}\text { Severe anemia and loss of } \\
\text { strength }\end{array}$ & $\begin{array}{l}1 \text { bean sized, upper rectum; } 1 \\
\text { smaller, lower sigmoid }\end{array}$ & 2 & 63 & $\sigma$ & . & \\
\hline 13 & Rectal distress & $\begin{array}{l}\text { Polyp previously removed and } \\
\text { hemorrhoids operated on } 3 \\
\text { times }\end{array}$ & $\begin{array}{c}\text { None now } \\
\text { seen }\end{array}$ & 45 & $\sigma^{\prime \prime}$ & 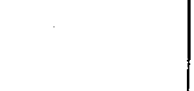 & $\begin{array}{l}\text { Previous removal of polyp and } \\
\text { hemorrhoids; no recurrence }\end{array}$ \\
\hline
\end{tabular}

* In this column, $\sigma$ denotes male and $q$ female.

or less indifferent mucosa. Here, also, there may be tubules lined with cylindric epithelium resembling an adenoma. ${ }^{13}$ Some authors ${ }^{14}$ think that the condition of multiple polyposis does not originate in the isolated type of polypi, and that the multiple polyposis tends specifically to the development of carcinoma. In gastric polyposis, Finney and Friedenwald ${ }^{13}$ report that polypi of the stomach are usually benign in character; but they observed one of two cases reported to be undergoing carcinomatous degeneration. Delafield and Prudden ${ }^{15}$ state that in some adenomas of the colon the tubules are irregular in shape and arrangement, and the growth infiltrates the surrounding parts, and

12. Doering, H.: Die Polyposis intestini und ihre Beziehung zu carcinomatosen Degeneration, Arch. f. klin. Chir., 1907, 83, 194. 13. Doering (Note 12). Finney and Friedenwald: Gastric Polyposis, Am. Jour. Med. Sc., 1917, 154, 683.

14. Earle, S. T.: Diseases of the Anus, Rectum and Sigmoid, 1911 p. 689 .
Borelius and Sjovall, however, showed that in a case with varying degrees of inflammation, both conditions were present, the pedicle coming from the submucosa as a result of the more extensive inflammation. Multiple polyposis of the colon may occur secondary to inflammatory changes in the mucosa, by the scarring and the mucosal excrescences in dysentery and tuberculosis. ${ }^{15}$

While the adenomatous type of polypi may degenerate into carcinoma more frequently, the connective tissue polyp is also associated with malignancy; and while the epithelium may appear indifferent, the polyp or the conditions producing it may also predispose to

16. Kaufmann: Spezielle pathologische Anatomie, Ed. 5, Berlin, 1909. Hauser, Schmoler, Schwab and Lahm, quoted by Borelius and Sjovali (Note 18).

17. Versé, quoted by Kaufmann (Note 16)

18. Borelius and Sjovall: Ueber Polyposis intestini, Beitr. z. klin. Chir., 1916, 99, 424 .

19.' Wechselmann, quoted by Borelius and Sjovall (Note 18). 
carcinoma. In Table 2, Case 1 , in which a severe colitis existed, one of the polyps was found to be adenomatous. In Case 11 it was papillomatous in type, while in Case 3 there was found chronic inflammation in the polyp associated with a cancer.

A few writers report solitary or a few scattered polypi associated with carcinoma, but mention their benign character. As mentioned above, in three of my cases (Table 2, Cases 2, 3 and 7 ) a carcinoma was present when there were solitary or a few scattered polypi. The unusual frequency of carcinoma with solitary or scattered polypi should be emphasized, for there probably is only a difference of degree in the proper stimulation, such as chronic inflammation or trauma for producing either solitary polypi, or a very grave disease, multiple polyposis. Since carcinoma develops early in about one half of the cases of multiple polyposis before they terminate in other complications, some specific predisposition must exist. Prophylactic treatment against all causes of chronic irritation or inflammation of the rectum and sigmoid, and active treatment in all stages of polypi, are advocated. ${ }^{20}$

122 South Michigan Avenue.

\section{Clinical Notes, Suggestions, and New Instruments}

REPLACEMENT OF SCALP ON A DENUDED DRY SKULL BY GRANULATIONS SECURED, THROUGH HOLES DRILLED IN THE BONE

T. C. Davison, M.D., Atlanta, Ga.

Associate Professor of Surgery, Emory University School of Medicine; Visiting Surgeon, Georgia Baptist Hospital; Associate Visiting Surgeon, Grady Hospital; Major, M. R. C., U. S. Army

In this case there was successful development of a covering of granulation tissue and epithelium over a skull dome, the bones of which were exposed, dry and undergoing necrosis. Grafts could not be attempted because of the bones' condition, and the usual tissue and blood supply for flaps in this area had also been destroyed.

The clothing of a girl of 6 caught fire. She threw herself, face downward, under the bed and protected her face by her right arm. The lower edge of the burned area extended across her back from the right lower costal margin to the angle of the left scapula. From this line the burn extended upward and, besides the head and neck burns, involved the back of both shoulders, more especially the right, and the extensor surface of the right arm. On the head and neck the burns and resultant sloughs involved the nape and right side of the neck, the scalp over the occiput to an irregular height of about 1 inch above the occipital protuberance, and the right ear. A ribbon-like burned area about an inch wide and an inch above the eyes extended across the right temple and forehead and caught the left ear in its subsequent scar. The left postauricular area was the only part of the base of the scalp that did not later slough, and the left posterior auricular artery was the only blood supply to the scalp not destroyed. The face, protected by the arm, escaped injury and remained uninvolved throughout. The scalp above the occiput, except for the ribbon-like burn, escaped immediate injury, though later sloughing.

20. In addition to the references already given. the following will be found of interest:

Rosenheim, L.: Zur Kenntnis der infiltrierenden Colitis und Sigmoiditis, Deutsch. med. Wchnschr., 1907, 33, 411.

Schwarz and Novascinsky: Eigenartige Röntgenbefunde von Dickdarm bei tiefgreifenden chronisch entzündlichen Prozessen, Wien. darm bei tiefgreifenden chronisch
klin. Wchnschr., 1912, 25, 1447.

McMahon and Carman: Chronic Colitis and its Roentgenologic Find-

ings, Jour. Lab. and Clin. Med., 1917, $\mathbf{2}, 328$.

Cripps, W. H.: Disease of Rectum and Anus, Ed. 3, 1917.
At the time of the child's admission to the hospital, three weeks after the burn was received, the burned area was a mass of infected, sloughing tissue giving off a very offensive odor and, because of the child's intractability, requiring six nurses to dress. The burns were treated antiseptically until healthy, and then those on the back, shoulders, neck and right arm were successfully skin-grafted. Because of the lack of any blood supply except the left posterior auricular artery, the scalp over the crown, above the burned area, underwent dry gangrene, and, much like a piece of leather, was painlessly pulled off by the attending surgeon two weeks after the hospital admission, the pericranium sloughing with the mass. The removal of the slough left the bone bare for an area of approximately 4 by 6 inches. The wounds around the bare bone became healthy; granulations spread out, but, for the lack of circulation, they extended only a short distance over the denuded area. The bone began to undergo necrosis and softened in spots, but at the same time granulations appeared through the two parietal foramina and, to a slight extent, through the suture line between the two parietal bones. This suggested that if there was enough foramina there would be enough granulation to cover the surface. Skin for flaps was not available, the skin of the neck having already been destroyed; Tiersch and pinch grafts would not grow on the dry and softening bone. So, instead, I drilled about fifty holes through the dry calvarium at the intersection of squares measuring $1 \mathrm{~cm}$. each way. The purpose of the drilling was to obtain a blood supply; so when blood was drawn the drilling stopped. In the softened areas, over the parietal eminences, the drill at times went through more quickly than expected, punctured the dura, and permitted the escape of cerebrospinal fluid.

The immediate postoperative reaction was a rise of temperature reaching a maximum of $105 \mathrm{~F}$., but lasting only twenty-four hours. Aside from this there was no postoperative symptom nor suggestion of meningeal complication.

Careful daily observation of the drill wounds was made. On the fifth day granulations began to appear in many of the holes; in other holes, granulations were delayed; and through some of the holes in the softened areas over the parietal eminences no granulations appeared at all. The granulations grew rapidly, spread out, mushroom-like, over the denuded area, and where they met they fused, thus gradually, over a course of weeks, covering the whole area. In trimming off exuberant granulations, the scissors encountered gritty resistance, as though from developing bone. The epithelium, unaided by grafts, extended from the slough edge upward over the granulations toward the dome for an irregular height of from $1 \frac{11}{2}$ to 2 inches. The remainder of the area over the vertex was covered in by pinch grafts, three attempts in all being necessary. Tiersch grafts, first tried, were entirely unsuccessful in this area, though successful on the back, arms and neck. It was impossible to control the child, and she destroyed many of the grafts mechanically.

Over the right parietal eminence there appeared a thickening which threatened to become a bony tumor. This stopped growing after the area covered over, and though it persists, it is not enlarging. A slight growth of hair, irregularly distributed, has appeared over the grafted area.

The child was admitted to the hospital in December, 1915, and was discharged the following July.

The Uric Acid Theory.-It is an extraordinary attribute to Alexander Haig that the curious heresy which he invented and preached should have been blindly accepted by two generations of his medical brethren, and have ultimately become an obsession with the laity. And the tribute is the more astounding from the fact that the treatment which the heresy demanded entailed, according to the hitherto accepted standards, very considerable self-denial. Moreover, the heresy appealed not only to the faddist. The sane, sober, commonsensical doctor accepted it, in spite of the fact that he had never been taught it in the schools. The awakening was a long time in coming; but it came, and now one seldom hears of uric acid, except from a patient.-Sinapis in Medical Press and Circular. 